\title{
The diversity of entomopathogenic fungi collected from leaves and rhizospheres of rice implementing integrated pest management
}

\author{
AMINUDIN AFANDHI ${ }^{1, \bullet}$, ELYKA PUTRI PERTIWI ${ }^{1}$, DICKY PREJEKI PURBA ${ }^{1}$, TITA WIDJAYANTI ${ }^{1}$, \\ AMIN SETYO LEKSONO ${ }^{2}$ \\ ${ }^{1}$ Faculty of Agriculture, Universitas Brawijaya. Jl. Veteran, Malang 65145, East Java, Indonesia \\ ${ }^{2}$ Deparment of Biology, Faculty of Mathematics and Natural Sciences, Universitas Brawijaya. Jl. Veteran, Malang 65145, East Java, Indonesia. \\ Tel.: +62-341-575841, Fax.: +62-341-554403, `email: amin28@ub.ac.id
}

Manuscript received: 20 March 2020. Revision accepted: 21 May 2020.

\begin{abstract}
Afandhi A, Pertiwi EP, Purba DP, Widjayanti T, Leksono AS. 2020. The diversity of entomopathogenic fungi collected from leaves and rhizospheres of rice implementing integrated pest management. Biodiversitas 21: 2690-2695. Rice is an important food source for most of the world's population. However, its production often faces pest and disease problems. This study aimed to determine the diversity of entomopathogenic fungi from the leaves and rhizospheres of rice plants, implementing applied integrated pest management (IPM), and to test the pathogenicity of insect fungi species against Spodoptera litura and Tenebrio molitor larvae collection. Entomopathogenic fungi were collected from the leaves and rhizospheres of two rice fields: a field in which IPM is implemented and a conventional field. A total of 24 species were collected from the leaves and rhizospheres in three locations. Pathogenicity test against $S$. litura larvae was conducted using the Beauveria sp. isolate, whereas pathogenicity test against $T$. molitor was conducted using the other isolates. Paddy fields in which IPM has been implemented have higher diversity and species richness compared with a conventional field. Location 1 (3 years of IPM implementation) has the highest diversity ( 2.04 of leaf collection and 1.65 of rhizosphere collection), location 2 has the lowest fungi diversity collected from rhizosphere, whereas location 3 (conventional implementation) has the lowest diversity of leaf collection (1.68). Laboratory testing of Beauveria spp. against $S$. litura revealed that all species were effective for pest control. Entomopathogenic fungi collected from leaves (Paecilomyces sp.) increased T. molitor mortality by $60 \%$, whereas those isolated from rhizospheres had no effective control of the pest.
\end{abstract}

Keywords: Diversity, entomopathogen, Integrated Pest Management, rhizosphere, Spodoptera litura

\section{INTRODUCTION}

Asian rice (Oryza sativa L.) is an important food crop, because it produces rice which is a source of staple food consumed by almost all Indonesian people (Thorburn 2015). Rice is consumed by approximately $98 \%$ of Indonesia's population, with an average consumption level of $114.13 \mathrm{~kg} / \mathrm{capita} / \mathrm{year}$. The demand for rice continues to increase due to an estimated population increase of $1.49 \%$ per year, as well as an increase in population income. In meeting the demands for rice, several obstacles can be encountered, including insect pests during rice cultivation, such as rice stem borer $(23.70 \%)$ and rice leaf folder (Cnaphalocrocis medinalis) (12.10\%). The existence of these pests, if not controlled, can significantly damage the plants, resulting in the loss of crop productivity (Trizelia 2015).

Currently, rice farmers carry out pest control using synthetic pesticides that do not meet the recommended dosage. Excessive and unwise use of synthetic pesticides causes environmental problems, especially increased resistance to targeted pests, explosion of non-target pest populations, the killing of natural enemies and other useful insects, contamination of soil and water, and decreased biodiversity (Leksono et al. 2019).

Many other pest control methods, such as the use of biological agents, can be employed as alternatives to the use of synthetic pesticides. One alternative pest control method is the utilization of biological agents, namely, entomopathogenic fungi. The use of entomopathogenic fungi is involved in the concept of integrated pest management (IPM). Microorganisms, such as fungi, bacteria, and viruses, also play a significant role in examining insect populations ( $\mathrm{Li}$ et al. 2010; Kachhawa 2017). These microorganisms also include insect parasitic fungi, which worsen epizootic than bacteria and viruses, and they are distributed worldwide. Many entomopathogenic fungi were evaluated as possible control agents for various insect pests, including samples from Indonesia (Hasyim et al. 2009; Nurariaty et al. 2013; Trizelia 2015; Safitri et al. 2018).

There are more than 700 types of entomopathogenic fungi, representing 90 genera (Goettel et al. 2010; Herlinda 2010; Alice et al. 2014), including Aspergillus sp. (Bawin et al. 2016), Fusarium sp., Penicillium sp., Rhizopus sp., Trichoderma sp. (Assaf et al. 2011), which have been widely studied in the Asia Pacific region. Entomopathogenic fungi derived from plants can be used to control pests. Numerous previous studies have been conducted to evaluate the effectiveness of these entomopathogenic fungi, both in the laboratory and in the field. Several tests that have been conducted on S. litura using $B$. bassiana have shown to be effective in reducing this species' ability to restore and develop (Malarvannan et 
al. 2010; Kaur et al. 2011; Ummidi and Vadlamani 2014; Ullah et al. 2019). Metarhizium, Beauveria, and Aspergillus have the highest diversity of entomopathogenic fungi found in the tomato plant rhizosphere. Nurariaty et al. (2013) revealed that the mortality of pupae and cocoa pod borer infecting the genus entomopathogenic fungi Penicillium sp., Aspergillus sp., and Fusarium sp. Entomopathogenic fungi are also effective in controlling mustard aphids (Lipaphis erysimi) in canola (Brassica napus L.) (Ujjan and Shahzad 2012).

In formula form, the combination of mycoinsecticide of Beauveria bassiana and Metarhizium anisopliae reduces the population of Myzus persicae in cabbage and lesser mealworms, Alphitobius diaperinus, in chicken broiler houses and (Michereff et al. 2011; Rice et al. 2020). Potential entomopathogens have also been evaluated in Beauveria bassiana, M. anisopliae, and Bacillus thuringiensis for the management of Helicoverpa armigera (Hubner). The results of this study indicate that the combination of the fungus is able to control H. armigera. Entomopathogenic fungi, Hirsutella thompsonii, and Paecilomyces fumosoroseus, are also effective against the citrus brown mite, Eutetranychus orientalis (Acari: Tetranychidae) (El-Sharabasy 2015).

The initial step required to utilize entomopathogenic fungi for rice pest control is to know the diversity of fungi species found in the rice ecosystem. To get the entomopathogenic fungus can be done by isolating it from various places, including the rhizosphere and leaves of rice farmland. This study aimed to determine the diversity of entomopathogenic fungi from the leaves and rhizosphere of the rice plant in the IPM implementing land and conventional ecosystem in the Malang Regency and to test the pathogenicity of insect fungi species against $S$. litura and T. molitor larvae.

\section{MATERIALS AND METHODS}

Analysis of the diversity of entomopathogenic fungi of rice leaves and rhizosphere was conducted in several stages. Furthermore, this study was conducted in three locations represent different pest management systems. The first location has been implementing IPM since 2016 (4 years), the second location has a yearly implementation, whereas the control has no IPM implementation.

At each location, leaves were collected from five healthy plants, whereas soils were collected from five points. Rice leaf sampling was performed when the plants were aged 38-42 days after planting (DAP). In the laboratory, leaves were soaked in $100 \mathrm{ml}$ of sterile Aqua Dest in an Erlenmeyer flask and were shaken using a shaker machine for $60 \mathrm{~min}$. The immersion was taken $1 \mathrm{ml}$ using a micropipette, followed by a dilution plate (dilution plate) to $10^{5}$ and poured on a Petri dish containing Sabouraud dextrose agar media that has been added with antibiotics. For the dilutions of $10^{-3}$ to $10^{-5}, 1 \mathrm{ml}$ was obtained and cultured in a Petri dish containing media with solid yeast extract. Breeding results were observed 3 days after capturing, assuming that all microbes had grown.

Purification was performed on each fungal colony which was considered different based on macroscopic morphology, including color and shape. Each of these microorganisms was obtained using a loose needle was then grown on media Petri dishes. Of the several fungal colonies grown in Petri dishes, if there were those that have the same macro characteristics, then one of the colonies was taken to be purified.

Identification was based on the fungi identification guidelines. Macroscopic observations included the color of the colony, the shape of the colony in a Petri dish (concentric and non-concentric), the texture of the colony, and the growth of the colony ( $\mathrm{cm} /$ day). Microscopic observations include the presence or absence of septal in hyphae (insulated), hyphal growth (branched or unbranched), the presence or absence of conidia, hyphal color and conidia (dark or transparent hyaline), and the shape of conidia (round, oval, branched, or chained) or irregular).

Calculation of the diversity of entomopathogenic fungus was performed using the Shannon-Wiener Diversity Index. The pathogenicity test against $S$. litura larvae was conducted using Beauveria sp. isolate, whereas test against T. molitor was conducted using other isolates. The pathogenicity test of $B$. bassiana was based on the application of $B$. bassiana isolate as a biological control agent in IPM fields, and T. molitor was used for new fungi found in the field. The isolate density used for this test was $10^{7}$ and was repeated three times. Each treatment used 20 individual larvae. The dip method was applied using $10 \mathrm{ml}$ of each suspension obtained from the Petri dish. The third instar of $S$. litura was soaked in a conidia suspension of Beauveria sp. mixed with $10 \mathrm{ml}$ of distilled water $0.1 \%$ Tween 80 for 5 seconds and dried on sterile tissue. The control was carried out by soaking $S$. litura larvae in sterile distilled water. $S$. litura larvae were transferred to plastic containers containing suspension. After air-drying under laminar flow for $10-15 \mathrm{~min}$, the larvae were kept individually in the rearing tubes and allowed to feed on castor bean leaves.

Larvae mortality $(\%)=\mathrm{A} / \mathrm{D} \times 100 \%$

Note:

A: number of death larvae

D: number of total larvae

If $T$. molitor and S. litura larvae are found dead in the control treatment with a condition of less than $20 \%$, then corrected using the formula:

$$
(\mathrm{A}-\mathrm{D}) / \mathrm{A} \times 100 \%
$$

Note:

A: percentage of surviving larvae in the control

D: percentage of surviving larvae in the treatment 
Table 1. Differences in crop cultivation practices in integrated pest control (IPM) and conventional (CNV) ecosystems

\begin{tabular}{|c|c|c|c|}
\hline \multirow{2}{*}{$\begin{array}{l}\text { Cultivation } \\
\text { practice }\end{array}$} & \multicolumn{3}{|c|}{ Ecosystems } \\
\hline & IPM of location 1 & IPM of location 1 & CNV \\
\hline Location & S 0704'26”' & S $07^{\circ} 02^{\prime} 33^{\prime \prime}$ & S $07^{\circ} 00^{\prime} 18^{\prime \prime}$ \\
\hline & E $112^{\circ} 13^{\prime} 22^{\prime \prime}$ & E $112^{\circ} 13^{\prime} 01^{\prime \prime}$ & E $112^{\circ} 12^{\prime} 08^{\prime \prime}$ \\
\hline Rice variety & Inpari 32, M400 & M400 & Ciherang \\
\hline Production & Approx. 8 ton/ha & Approx.8 ton/ha & Approx.7 ton/ha \\
\hline $\begin{array}{l}\text { Pest and natural } \\
\text { enemies' } \\
\text { observation }\end{array}$ & $\begin{array}{l}\text { Perform routine when seeding and planting } \\
\text { once a week }\end{array}$ & $\begin{array}{l}\text { Perform routine when seeding and planting } \\
\text { once a week }\end{array}$ & No observation \\
\hline Pesticide & $\begin{array}{l}\text { Applied when pest population is above the } \\
\text { economic threshold, causing many } \\
\text { symptoms and attacks on rice plants. } \\
\text { Control using pesticides is done to } \\
\text { minimize yield shortages or crop failure }\end{array}$ & $\begin{array}{l}\text { Applied when pest population is above the } \\
\text { economic threshold, causing many } \\
\text { symptoms and attacks on rice plants. Control } \\
\text { using pesticides is done to minimize yield } \\
\text { shortages or crop failure }\end{array}$ & $\begin{array}{l}\text { Applied 2-3 times } \\
\text { during the planting }\end{array}$ \\
\hline Biological agent & $\begin{array}{l}\text { Beauveria bassiana and PGPR (plant } \\
\text { growth-promoting rhizobacteria) }\end{array}$ & Beauveria bassiana, and PGPR & None \\
\hline Fertilizer & Nitrogen, $\mathrm{Zn}$, and liquid organic fertilizer & Nitrogen, $\mathrm{Zn}$, and liquid organic fertilizer & $\begin{array}{l}\text { Synthetic fertilizer } \\
\text { and compost }\end{array}$ \\
\hline $\begin{array}{l}\text { Fertilizer } \\
\text { application }\end{array}$ & $\begin{array}{l}\text { Application of compost and liquid organic } \\
\text { fertilizer during vegetative and generative } \\
\text { growth }\end{array}$ & $\begin{array}{l}\text { Application of compost (before planting), } \\
\text { liquid organic fertilizer during vegetative } \\
\text { and generative growth }\end{array}$ & $\begin{array}{l}\text { Applied 2-3 times } \\
\text { during the planting }\end{array}$ \\
\hline
\end{tabular}

\section{RESULTS AND DISCUSSION}

\section{Results}

A total of 24 species were collected from the leaves and rhizosphere of rice ecosystem in three locations. Rice fields implementing IPM had higher fungi diversity and species richness both of the leaves and rhizosphere collection compared to that of conventional land. The first IPM location had 98 colonies belonging to 8 species, with 2.04 species diversity of leaf collections. The second IPM location had 69 colonies belonging to 8 species, with 2.00 species diversity. The conventional location had 32 colonies belonging to 4 species with 1.68 species diversity. A similar situation was observed in the rhizosphere collection, except for fungi diversity in the second location. The first IPM location had 55 colonies belonging to 6 species, with 1.65 species diversity of rhizosphere collections. The second IPM location had 41 colonies belonging to 5 species, with 1.15 species diversity. The conventional location had 30 colonies belonging to 3 species, with 1.31 species diversity.

The results of pathogenicity testing using Beauveria sp. fungi against $S$. litura revealed that species number 3 had the highest pathogenicity $(61.67 \%)$, whereas species numbers 1 and 2 had pathogenicity of $51.67 \%$ and $53.33 \%$, respectively. The test was not conducted using isolates from rhizosphere because there was no Beauveria spp. collection.

In the Koch postulate test, the pathogenicity of the entomopathogenic fungi against $T$. molitor revealed different results. Those derived from leaf collection had the highest $T$. molitor mortality, which resulted in the treatment using Paecilomyces sp. by $60 \%$, followed by Aspergillus sp. 6 by 40\%, Aspergillus sp. 1 to $36.67 \%$ and Aspergillus sp. 2 at $36.67 \%$ (Table 4). Those isolated from the rhizosphere had low $T$. molitor mortality. The highest $T$. molitor mortality was observed in the test using Fusarium sp. 1 (30\%), followed by Fusarium sp. 2 (30\%), and Fusarium sp. 3 (16.67\%). The other isolates had lower $T$. molitor mortality, which was less than $15 \%$.

Carbon and organic matter content in rice rhizosphere based on location $1(1.48 \%$ and $2.55 \%)$ is the highest compared with that of location $2(1.22 \%$ and $2.10 \%)$ and location 3 (1.24\% and 2.14\%) (Table 6).

\section{Discussion}

The diversity of entomopathogenic fungi derived from the leaf collection was different in the IPM and conventional ecosystems. The difference in the diversity level was caused by crop cultivation and the estimated time of IPM application in the ecosystem. The biological agents applied in the IPM of rice ecosystems were Beauveria bassiana, decomposer, and PGPR, whereas conventional applications do not apply biological agents. The ecosystems implementing IPM were more suitable for entomopathogenic fungi due to low chemical use and high organic fertilizer use. But in the conventional ecosystem, pesticide and synthetic fertilizers were applied two to three times during the planting; it is not a suitable environment for entomopathogenic fungi. Organic fertilizers can trigger decaying plant tissue as a substrate for the entomopathogenic fungal mycelium and thus increase the abundance of local entomopathogenic fungi. Such an assortment of niches has resulted in these fungi evolving a considerable morphological diversity, which resulted in enormous biodiversity (Araújo and Hughes 2016). Ecosystems implementing IPM are considered a more suitable environment for entomopathogenic fungi, and biotic factors and planting practices, such as land preparation, greatly impact the abundance of entomopathogenic fungi. Another relevant study revealed that the total diversity of entomopathogenic fungi was higher in organic compared with conventional land (Clifton et al. 2015). The diversity index in the IPM ecosystem was 
categorized as medium (above 1). Community diversity was characterized by the many species of organisms that make up the community-the more species, the higher the diversity.

Several studies demonstrated that IPM ecosystems support more entomopathogenic fungi than conventional ecosystems. A study on fungi from the rhizosphere collection in the IPM ecosystem found the number of genus and species of entomopathogenic fungi, which had a higher frequency of colonization compared with conventional ecosystems (Noerfitryani 2018). The high diversity of the entomopathogenic fungi in the IPM ecosystem was caused possibly by several factors. First, the IPM ecosystem is preferred for fungal colonization due to the low use of chemicals and high use of organic fertilizers. Both biotic factors and planting practices, such as land preparation, have a great impact on the abundance of entomopathogenic fungi. The use of mycoinsecticides has the potential to play a key role in IPM programs for effective and relatively safe IPM in field crops. Until now, mycoinsecticides in the form of commercial products has been widely produced. Generally, the types used are Beauveria bassiana, M. anisopliae, and Isaria fumosoroseus (Hafiza et al. 2014; Maina et al. 2018).

The diversity of entomopathogenic fungi in an ecosystem is affected by the magnitude of density and the number and extent of distribution of each species. To determine the level of stability of entomopathogenic fungi diversity, diversity index values can be used. Species stability is also influenced by the level of diversity-the higher the value of diversity, the more stable the diversity of species in the ecosystem. The type that has a high level of stability has a greater opportunity to maintain its sustainability (Handoko et al. 2017).

The Beauveria species number 3 application revealed a high potential against $S$. litura, with a mortality rate of more than $60 \%$. Hasyim et al. (2009) reported that, in general, insects can be infected by conidia of entomopathogenic fungi through contact with the cuticles or through gaps between body segments. Conidia of entomopathogenic fungi generally infect and germinate in a suitable host, initiating enzyme recognition, and activation reaction (Shahid 2012). The more conidia Beauveria sp. attached to the body of $S$. litura larvae, the mortality of larvae increased. Other factors causing the mortality of $S$. litura larvae are the density and viability of fungi. Fungal isolates from rice leaves had different conidia density and viability. The higher the conidial density is infected, the higher the chance of contact between the pathogen and its host.

Application of fungi originating from leaves to $T$. molitor showed that Paecilomyces sp. exhibited high potential as a controlling agent against $T$. molitor, whereas fungi originating from the rhizosphere were less effective because the mortality rate was less than $50 \%$. Observations performed until the 10th day revealed symptoms of infection arising in the T. molitor larvae. Symptoms of infected test insects showed the characteristic color of the body from light brown, turn blackish brown and turn black again. At the time, the body of $T$. molitor larvae became blackish brown, and their movements in the vial became passive. When the body of the larvae became black, visible tissue and fluid came out. The use of synthetic fertilizer on the soil affects the population of microorganisms in the soil; improper use reduces virulence and fungus propagation (Garrido-Jurado et al. 2011).

Table 2. Genus and types of fungi from leaves and rhizosphere derived from three different ecosystems

\begin{tabular}{|c|c|c|c|}
\hline \multirow{2}{*}{ Fungi species } & \multicolumn{3}{|c|}{ Number of colonies } \\
\hline & $\begin{array}{c}\text { IPM of } \\
\text { location } 1\end{array}$ & $\begin{array}{c}\text { IPM of } \\
\text { location } 2\end{array}$ & $\begin{array}{c}\text { Conventio } \\
\text { nal }\end{array}$ \\
\hline \multicolumn{4}{|l|}{ Leaf collections } \\
\hline Acremonium sp. & - & - & 8 \\
\hline Aspergillus sp. 1 & 10 & - & - \\
\hline Aspergillus sp. 2 & - & 12 & - \\
\hline Aspergillus sp. 3 & - & 8 & - \\
\hline Aspergillus sp. 4 & - & 8 & - \\
\hline Aspergillus sp. 5 & 15 & - & - \\
\hline Aspergillus sp. 6 & - & - & 7 \\
\hline Aspergillus sp. 7 & 9 & - & - \\
\hline Aspergillus sp. 8 & - & - & 11 \\
\hline Aspergillus sp. 9 & - & - & 6 \\
\hline Beauveria sp. 1 & 14 & - & - \\
\hline Beauveria sp. 2 & 19 & - & - \\
\hline Beauveria sp. 3 & - & 15 & - \\
\hline Paecilomyces sp. & - & 5 & - \\
\hline Penicillium sp. 1 & 12 & - & - \\
\hline Penicillium sp. 2 & - & 7 & - \\
\hline Penicillium sp. 3 & - & 10 & - \\
\hline Rhizopus sp. 1 & 8 & - & - \\
\hline Rhizopus sp. 2 & - & 4 & - \\
\hline Rhizopus sp. 3 & 11 & - & - \\
\hline No. of colonies & 98 & 69 & 32 \\
\hline No. of species & 8 & 8 & 4 \\
\hline Species diversity & 2.04 & 2.00 & 1.68 \\
\hline \multicolumn{4}{|l|}{ Rhizosphere } \\
\hline Trichoderma sp. 1 & 1 & - & - \\
\hline Trichoderma sp. 2 & - & 1 & - \\
\hline Aspergillus sp.10 & 9 & 2 & 9 \\
\hline Aspergillus sp.11 & 11 & 6 & \\
\hline Fusarium sp. 1 & 6 & 24 & 17 \\
\hline Fusarium sp. 2 & - & 8 & - \\
\hline Fusarium sp. 3 & 12 & - & - \\
\hline Unidentified & 10 & - & 4 \\
\hline No. of colonies & 55 & 41 & 30 \\
\hline No. of species & 6 & 5 & 3 \\
\hline Species diversity & 1.65 & 1.15 & 1.31 \\
\hline
\end{tabular}

Table 3. Pathogenicity of Beauveria spp. from the leaf collection against of $S$. litura

\begin{tabular}{lccc}
\hline Fungi isolate & $\begin{array}{c}\text { Viability } \\
(\boldsymbol{\%})\end{array}$ & $\begin{array}{c}\text { Density } \\
\left(\mathbf{( 1 0}^{\mathbf{7}}\right)\end{array}$ & $\begin{array}{c}\text { Mortality } \\
(\boldsymbol{\%})\end{array}$ \\
\hline Beauveria sp. 1 & 61.4 & 1.2 & 51.67 \\
Beauveria sp. 2 & 62.3 & 2.0 & 53.33 \\
Beauveria sp. 3 & 63.2 & 4.2 & 61.67 \\
\hline
\end{tabular}


Table 4. Pathogenicity of some fungi derived from the leaves to T. molitor larvae

\begin{tabular}{|c|c|}
\hline Isolate & Mortality (\%) \\
\hline Control & 0 \\
\hline Acremonium sp. & 26.67 \\
\hline Aspergillus sp. 1 & 36.67 \\
\hline Aspergillus sp. 2 & 36.67 \\
\hline Aspergillus sp. 3 & 30 \\
\hline Aspergillus sp. 4 & 33.33 \\
\hline Aspergillus sp. 5 & 33.33 \\
\hline Aspergillus sp. 6 & 40 \\
\hline Aspergillus sp. 7 & 33.33 \\
\hline Aspergillus sp. 8 & 26.67 \\
\hline Aspergillus sp. 9 & 26,67 \\
\hline Paecilomyces sp. & 60 \\
\hline Penicillium sp. 1 & 26.67 \\
\hline Penicillium sp. 2 & 30 \\
\hline Penicillium sp. 3 & 26.67 \\
\hline Rhizopus sp. 1 & 23.33 \\
\hline Rhizopus sp. 2 & 23.33 \\
\hline Rhizopus sp. 3 & 26.67 \\
\hline
\end{tabular}

Table 5. Pathogenicity of some fungi originating from the rhizosphere against $T$. molitor larvae

\begin{tabular}{ll}
\hline \multicolumn{1}{c}{ Isolate } & Mortality $(\%)$ \\
\hline Aspergillus sp. 10 & 13.33 \\
Aspergillus sp. 11 & 6.67 \\
Fusarium sp. 1 & 30 \\
Fusarium sp. 2 & 20 \\
Fusarium sp. 3 & 16.67 \\
Trichoderma sp 1 & 0 \\
Trichoderma sp 2 & 0 \\
Unknown & 0 \\
\hline
\end{tabular}

Table 6. Physical and chemical characteristics from three locations

\begin{tabular}{lccc}
\hline Parameter & \multicolumn{3}{c}{ Location } \\
\cline { 2 - 4 } & $\begin{array}{c}\text { IPM of } \\
\text { location } \\
\text { 1 }\end{array}$ & $\begin{array}{c}\text { IPM of } \\
\text { location } \\
\mathbf{2}\end{array}$ & $\begin{array}{c}\text { Conven- } \\
\text { tional }\end{array}$ \\
\hline $\mathrm{pH}\left(\mathrm{H}_{2} \mathrm{O}\right)$ & 7.75 & 7.91 & 7.31 \\
Organic carbon $(\%)$ & 1.48 & 1.22 & 1.24 \\
Organic matters $(\%)$ & 2.55 & 2.10 & 2.14 \\
Soil temperature $\left({ }^{\circ} \mathrm{C}\right)$ & 27 & 27 & 28 \\
Soil moisture $(\%)$ & 100 & 100 & 100 \\
\hline
\end{tabular}

The edaphic factors in the study sites were quite similar. The $\mathrm{pH}$ of the three agroecosystems was alkaline (>7). Mora et al. (2017) found a significant correlation between soil $\mathrm{pH}$ and the presence of entomopathogenic fungi, which are generally more tolerant to acidic $\mathrm{pH}$, even though B. bassiana was augmented by soil treatment. Organic matter plays an important role in the soil. The richer the organic matter content in the rhizosphere, the more diverse and abundant are beneficial soil microbes, including insect fungi. Organic matter content greatly affects the soil microbial population because organic matter is used as a constituent of the body and an energy source for soil microbes. The content of organic matter in the three ecosystems is included in the low category, so that it can be understood that the fertility index in the rice rhizosphere in the three ecosystems was relatively low. Zhong et al. (2010) stated that soils in ecosystems applying compost have higher $B$. bassiana propagule content than soils in ecosystems using synthetic fertilizers. This is due to the use of compost, which causes loose soil texture; thus, organic soil is able to maintain fungus propagation (Garrido-Jurado et al. 2011). Conversely, the application of synthetic pesticides can reduce the presence of entomopathogenic fungi in the soil (Mietkiewski et al. 2010). In addition to organic content, entomopathogenic fungi are also additives of temperature and compounds (Hsia et al 2014). In addition to organic content, entomopathogenic fungi viability was influenced by temperature and additive compounds (Hsia et al. 2014).

In conclusion, paddy fields in which IPM is implemented have higher diversity and species richness compared with conventional land. Location 1 (3 years of IPM implementation) has the highest diversity (2.04 of leaf collection and 1.65 of rhizosphere), location 2 has the lowest fungi diversity collected from rhizosphere, whereas location 3 (conventional implementation) has the lowest diversity of leaf collection (1.68). Laboratory testing of Beauveria spp. against $S$. litura revealed that all species were effective for controlling pests. Entomopathogenic fungi collected from leaves (Paecilomyces sp.) affected the highest mortality of $T$. molitor $(60 \%)$, whereas those isolated from the rhizosphere had no effective control of the pest because the mortality rate was less than $50 \%$.

\section{ACKNOWLEDGEMENTS}

The authors would like to thank farmers in the study sites who supported our field collection.

\section{REFERENCES}

Alice J, Sujeetha RP, Sahayaraj K. 2014. Role of Entomopathogenic Fungus in Pest Management. In: Sahayaraj K (eds.). Basic and Applied Aspects of Biopesticides. Springer, New Delhi. DOI 10.1007/978-81-322-1877-7_3.

Araújo JP, Hughes DP. 2016. Diversity of Entomopathogenic Fungi: Which Groups Conquered the Insect Body?. Adv Genet 94: 1-39. DOI: $10.1016 /$ bs.adgen.2016.01.001

Assaf LH, Haleem RA, Abdullah SK. 2011. Association of Enthomophatogenic and Other Opportunistic Fungi with Insects in Dormant Locations. Jordan J Biol Sci 4: 87-92.

Bawin T, Seye F, Boukraa S, Jean-Yves Z, Fara, NR, Quentin Z, Mady N, Farnk D, Frédéric F. 2016. Production of two entomopathogenic aspergillus species and insecticidal activity against the mosquito Culex quinquefasciatus compared to Metharizium anisoplae. J Biocontrol Sci Technol 26: 617-629.

Clifton EH, Jaronski ST, Hodgson EW, Gassmann AJ. 2015. Abundance of soil-borne entomopathogenic fungi in organic and conventional fields in the Midwest USA with an emphasis on the effect of herbicide and fungicides on fungal persistence. PLoS ONE 10: e0133613. DOI: 10.1371/journal.pone.0133613.

El-Sharabasy HM. 2015. Laboratory evaluation of the effect of the entomopathogenic fungi, Hirsutella thompsonii and Paecilomyces 
fumosoroseus, against the citrus brown mite, Eutetranychus orientalis (Acari: Tetranychidae). Plant Protect Sci 5: 39-45.

Garrido-Jurado J, Torrent J, Barrón V, Corpas A, Quesada-Moraga E 2011. Soil properties affect the availability, movement, and virulence of entomopathogenic fungi conidia against puparia of Ceratitis capitata (Diptera: Tephritidae). Biol Control 58: 277-285.

Goettel MS, Eilenberg J, Glare TR. 2010. Entomopathogenic Fungi and their Role in Regulation of Insect Populations. In: Gilbert LI, Gill SS (eds.). Insect Control Biological and Synthetic Agents, Elsevier, Nederlands.

Hafiza TG, Shafqat S, Fawad ZAK. 2014. Entomopathogenic fungi as effective insect pest management tactic: A review. Appl Sci Bus Econ 1 (1): 10-18.

Handoko RNS, Afandhi A, Leksono AS. 2017. Correlation of soil environment to diversity the entomopathogenic fungi. Indon J Environ Sustain Dev 8 (1): 36-42.

Hasyim A, Nuraida, Trizelia. 2009. Pathogenicity of entomopathogenic fungi isolates to eggs and larvae of cabbage head caterpillar, Crocidolomia pavonana Fabricius. J Hort 19: 334-343.

Herlinda S. 2010. Spore Density and Viability of Entomopathogenic Fungal Isolates from Indonesia, and Their Virulence against Aphis gossypii Glover (Homoptera: Aphididae). Trop Life Sci Res 21 (1): 11-19.

Hsia ICC, Touhidul IM, Ibrahim Y, How TY, Omar D. 2014. Evaluation of conidial viability of entomopathogenic fungi as influenced by temperature and additive. Intl J Agric Biol 16 (1): 146-152.

Kachhawa D. 2017. Microorganisms as a biopesticide. J Entomol Zool Stud 5 (3): 468-473.

Kaur K, Kaur HP, Kaur K, Kaur A. 2011. Effect of different concentrations of Beauveria bassiana on development and reproductive potential of Spodoptera litura (Fabricius). J. Biopestic 4 (2): 161-168.

Leksono AS, Batoro J, Zairina A. 2019. Abundance and composition of Arthropod visitors on refugia blocks in a paddy field in Malang East Java Indonesia. Ecol Environ Conserv 25 (1): 467-471.

Li Z, Alves SB, Roberts DW, Fan M, Delalbera I Jr, Tang J. 2010. Biological control of insects in Brazil and China: History, current programs and reasons for their successes using entomopathogenic fungi. Biocontrol Sci Technol 20: 117-136.

Maina UM, Galadima IB, Gambo FM, Zakaria D. 2018. A review on the use of entomopathogenic fungi in the management of insect pests of field crops. J Entomol Zool Stud 6 (1): 27-32.

Malarvannan S, Murali P, Shanthakumar S, Prabavathy V, Nair S. 2010. Laboratory evaluation of the entomopathogenic fungi, Beauveria bassiana against the tobacco caterpillar, Spodoptera litura Fabricius (Noctuidae: Lepidoptera). J Biopesticides 3: 126-131.
Michereff M, Oliveira S, de Liz RS, Faria M. 2011. Cage and field assessments of Beauveria bassiana-based Mycoinsecticides for Myzus persicae Suizer (Hemiptera: Aphididae) control in cabbage. Neotrop Entomol 40 (4): 470-476.

Mietkiewski RT, Pell JK, Clark SJ. 2010. Influence of pesticide use on the natural occurrence of entomopathogenic fungi in arable soils in the UK: Field and laboratory comparisons. Biocontrol Sci Technol 7: 565-575.

Mora MAE, Castilho AMC, Fraga ME. 2017. Classification and infection mechanism of entomopathogenic fungi. Arq Inst Biol 84: 1-10.

Noerfitryani N, Hamzah H. 2018. Inventarisasi Jenis-Jenis Cendawan Pada Rhizosfer Pertanaman Padi. Jurnal Galung Tropika 7 (1): 11-21. [Indonesian]

Nurariaty A, Saranga PA, Rosmana A, Tambingsila M. 2013. Potential of Rhizosphere Fungi as Biological Control Agent of Cocoa Plant Pests and Diseases. Proceedings of National Seminar and Congres of PFI XXI, Padang, 8-10 October 2013. [Indonesian]

Rice SJ, Baker DK, Mayer DG, Leemon DM. 2020. Mycoinsecticide formulations of Beauveria bassiana and Metarhizium anisopliae reduce populations of lesser mealworm, Alphitobius diaperinus, in chicken-broiler houses. Biol Control 144: 104234, DOI: 10.1016/j.biocontrol.2020.104234.

Safitri A, Herlinda S, Setiawan A. 2018. Entomopathogenic fungi of soils of freshwater swamps, tidal lowlands, peatlands, and highlands of South Sumatra, Indonesia. Biodiversitas 19 (6): 2365-2373.

Shahid AA, Rao AQ, Bakshs A, Husnain T. 2012. Entomopathogenic fungi as biological controllers: New Insight into their virulence and pathogenicity. Arch Biol Sci Balgrade 6 (1): 21-42.

Thorburn C. 2015. The rise and demise of integrated pest management in rice in Indonesia. Insects 6: 381-408

Trizelia, Armon N, Jailani H. 2015. Diversity of Entomopathogenic Fungi in the Rhizosphere of Various Vegetable plants. West Sumatra. Pros Sem Nas Masy Biodiv Indon 1 (5): 998-1004. [Indonesian]

Ujjan AA, Shahzad S. 2012. Use of entomopathogenic fungi for the control of mustard aphids (Lipaphi serysimi) on canola (Brassica napus L.). Pak J Bot 44: 2081-2086.

Ullah MI, Altaf N, Afzal M. 2019. Effects of entomopathogenic fungi on the biology of Spodoptera litura (Lepidoptera: Noctuidae) and its reduviid predator, Rhynocoris marginatus (Heteroptera: Reduviidae). Intl J Insect Sci 11: 1179543319867116. DOI: 10.1177/1179543319867116.

Ummidi VRS, Vadlamani P. 2014. Preparation and use of oil formulations of Beauveria bassiana and Metarhizium anisopliae against Spodoptera litura larvae. Afr J Microbiol Res 8 (15): 1638-1644.

Zhong W, Gu T, Wang W. 2010. The effects of mineral fertilizer and organic manure on soil microbial community and diversity. Plant Soil 326: $511-522$. 